\title{
Reexamination of the relationship between
}

\section{the prevalence of hepatitis $C$ virus and parenteral antischistosomal therapy among Egyptians resident in Qatar}

\author{
This article was published in the following Dove Press journal: \\ Clinical and Experimental Gastroenterology \\ 3 November 2014 \\ Number of times this article has been viewed
}

\author{
Moutaz Derbala ${ }^{1,2}$ \\ Prem Chandra ${ }^{3}$ \\ Aliaa Amer ${ }^{4}$ \\ Anil John' \\ Manik Sharma' \\ Ashraf Amin' \\ Ragesh Babu Thandassery' \\ Amr Faris ${ }^{5}$ \\ 'Gastroenterology and Hepatology \\ Department, Hamad Hospital, \\ ${ }^{2}$ Medical Department, Weill Cornell \\ Medical College, Qatar Branch, \\ ${ }^{3}$ Medical Research Center, Hamad \\ Medical Corporation, ${ }^{4}$ Laboratory \\ Medicine and Pathology Department, \\ ${ }^{5}$ Cardiovascular Surgery Department, \\ Hamad Hospital, Doha, Qatar
}

Correspondence: Moutaz Derbala Gastroenterology and Hepatology Department, Hamad Hospital, PO Box 3050, Doha, Qatar

Emailmod2002@qatar-med.cornell.edu

\begin{abstract}
Egypt has the highest prevalence of recorded hepatitis $\mathrm{C}$ virus (HCV) worldwide, estimated nationally at $14.7 \%$, which is attributed to extensive iatrogenic transmission during the era of parenteral antischistosomal therapy (PAT) mass-treatment campaigns. The objective of our study was to attempt to highlight to what extent HCV transmission is ongoing and discuss the possible risk factors. We studied the prevalence of $\mathrm{HCV}$ among 7.8\% of Egyptians resident in Qatar in relation to age, socioeconomic status, and PAT and discuss the possible risk factors. HCV testing was conducted in 2,335 participants, and results were positive for $13.5 \%$, and $8.5 \%$ for those aged below 35 years. The prevalence of $\mathrm{HCV}$ in the PAT-positive population was $23.7 \%$ (123 of 518, 95\% confidence interval [CI] 20.2\%-27.6\%) compared with $11.2 \%$ in the PAT-negative group. Significantly higher HCV prevalence occurred in participants who were older than 50 years $(23 \%, 95 \%$ CI $19.3 \%-27.1 \%)$ compared to those aged $45-50$ years $(19.3 \%$, 95\% CI 15.2\%-23.8\%), 35-45 years (11.1\%, 95\% CI 8.9\%-13.7\%), and less than 35 years $(8.5 \%, 95 \%$ CI 6.8\%-10.4\%) $(P<0.0001)$. Insignificant higher prevalence occurred in the low socioeconomic group $(14.2 \%, 95 \%$ CI $11.3 \%-17.4 \%)$. Logistic regression analysis revealed that increasing age, history of PAT, bilharziasis, and praziquantel were common risk factors, but there was no relation with dental care. Host genetic predisposition seems to be a plausible underlying factor for susceptibility among Egyptians and intense ongoing infection.
\end{abstract}

Keywords: epidemiology, HCV, schistosomiasis

\section{Introduction}

Hepatitis $\mathrm{C}$ virus $(\mathrm{HCV})$ is a leading cause of chronic liver disease worldwide. ${ }^{1}$ The World Health Organization estimates that 170 million people are infected with HCV globally and 3-4 million new infections occur annually. ${ }^{2}$ Egypt has the highest rate of antibodies to HCV worldwide, estimated nationally at $14.7 \%{ }^{3}$ This epidemiological situation is of significant concern and requires urgent, broad, and active intervention for the prevention and control of HCV. Primary prevention activities include: screening and testing of blood, plasma, tissue, organ, and semen donors, virus inactivation of plasma-derived products, risk-reduction counseling services, and implementation of infection-control practices. Secondary prevention activities include identification and testing of persons at risk and management of infected persons.

The high prevalence of $\mathrm{HCV}$ among Egyptians was attributed to the iatrogenic role of the parenteral campaign therapy that was carried out in the 1960s and 1970s to 
control endemic schistosomiasis using insufficiently sterilized intravenous injection equipment, ${ }^{4}$ which unfortunately established a very large reservoir of HCV. In spite of the fact that the mass-treatment campaign has been stopped, seroprevalence studies in Egypt have shown that the prevalence rates in children born after the end of mass treatment have been ranging between $1 \%$ and $10 \%$. 5,6

Extensive studies of risk factors for prevalent and incident infections in Egypt have been conducted. ${ }^{7,8}$ Unsterile syringes and contaminated blood or blood products could not account for a substantial proportion of present infections. Current HCV infection possibly has a strong familial component, explained at least partly by specific modes of intrafamilial viral transmission. ${ }^{9}$

National health care awareness and infection-control programs should be strengthened to prevent further transmission, ${ }^{10}$ but we should properly estimate the prevalence to improve our understanding of HCV epidemiology and encourage researchers to seek more information on how and why HCV being transmitted among certain populations, and to assist the Egyptian government in their preventive efforts.

Despite the various studies that have been conducted among different samples of the Egyptian population to examine the prevalence of $\mathrm{HCV}$ infection, an important question has been raised regarding HCV transmission in Egypt. Are the parenteral antischistosomal therapy (PAT) campaigns, which took place before 1985 the main cause of $\mathrm{HCV}$ transmission, and if yes, why does it continue? Therefore, the primary aim of this study was to study the prevalence of HCV among Egyptians resident in Qatar in relation to age, socioeconomic status, and PAT, and the secondary aim was to shed light on and analyze the possible risk factors responsible for the persistence of infection.

\section{Patients and methods}

\section{Ethics statement}

All patients provided written informed consent following the Declaration of Helsinki of 1979, and the study was approved by the local research and ethical committee of Hamad Hospital, Qatar. All study work was performed in accordance with national ethical regulations.

\section{Procedure}

A screening survey of 233 Egyptian people of 130,000 resident in Qatar (7.78\% of the population) was conducted from December 2008 through July 2010 in Qatar health centers and the Egyptian embassy. It was carried out in two phases, involving 1,834 cross-sectional and 501 rural area subjects with low socioeconomic status (low income and low education level while living in Egypt). Qualitative detection of HCV antibodies was done using a colloidal gold-enhanced rapid immunochromatographic assay (Health-Chem Diagnostics, Pompano Beach, FL, USA). ${ }^{11}$ Diagnosis of chronic HCV was confirmed by measuring the viral load using reversetranscription polymerase chain reaction (TaqMan ${ }^{\circledR}$, Amplicor Molecular System version 2.0; Hoffmann-La Roche, Basel, Switzerland), with a minimum detection limit of $50 \mathrm{IU} / \mathrm{mL}$, and those found positive underwent liver biopsy.

A total of 28 and 33 patients with proven chronic $\mathrm{HCV}$ formed the controls for validation of the kit used in the first and the second cohort, respectively, and these controls were not included in the statistics. HCV genotyping was tested using the Inno-LiPA HCV II assay (Innogenetics, Alpharetta, GA, USA). Questionnaires that included demographic and health information, number of dental care visits, PAT, intravenous drug use (IDU), and previous potential exposure to $\mathrm{HCV}$ infection were administered.

\section{Statistical analysis}

Descriptive statistics were used to summarize demographic and all other clinical characteristics of the participants. The primary outcome variable - the prevalence of $\mathrm{HCV}$ - was estimated and is presented along with $95 \%$ confidence intervals (CIs). Associations between two or more qualitative variables were assessed using $\chi^{2}$ or Fisher's exact tests as appropriate. Quantitative variable means between HCVpositive and -negative groups were analyzed using Student's unpaired $t$-test. Univariate and multivariate logistic regression analysis was carried out to examine and assess the association of various potential predictors and covariates, such as age, residential area, history of PAT, bilharziasis, and praziquantel with the outcome variable HCV. Logistic regression analysis results are presented in terms of odds ratios (ORs) and associated $95 \%$ CIs. A two-sided $P$-value $<0.05$ was considered to be statistically significant. All statistical analyses were done using SPSS 19.0 (SPSS, Chicago, IL, USA).

\section{Results}

During the study period - December 2008 to July 2010 - a total of 2,335 participants were enrolled and screened. For the 2,335 enrolled, age ranged from 18 to 69 years, with a mean age of $39.4 \pm 10.3$ years. All were males and Egyptian nationals. HCV testing was obtained in 2,335 participants, and the results were positive for 315 (13.5\%). Participants' baseline demographic and clinical characteristics are presented in Table 1. 
Table I Baseline demographic and clinical characteristics

\begin{tabular}{|c|c|c|}
\hline Characteristics & $\begin{array}{l}\text { Frequency } \\
(n=2,335)\end{array}$ & Percentage \\
\hline Age (years)* & $39.4 \pm 10.3(39[18-69])$ & \\
\hline \multicolumn{3}{|l|}{ Age group } \\
\hline$<35$ years & 908 & $38.9 \%$ \\
\hline 35 to $<45$ years & 658 & $28.2 \%$ \\
\hline 45 to $<50$ years & 322 & $13.8 \%$ \\
\hline$\geq 50$ years & 447 & $19.1 \%$ \\
\hline \multicolumn{3}{|l|}{ Sex } \\
\hline Male & 2,335 & $100 \%$ \\
\hline \multicolumn{3}{|l|}{ Nationality } \\
\hline Egyptian & 2,335 & $100 \%$ \\
\hline \multicolumn{3}{|c|}{ Residential/socioeconomic status } \\
\hline Urban & $\mathrm{I}, 834$ & $78.5 \%$ \\
\hline Low & 501 & $21.5 \%$ \\
\hline \multicolumn{3}{|l|}{ History of bilharziasis } \\
\hline Positive & 605 & $27.1 \%$ \\
\hline Negative & 1,625 & $72.9 \%$ \\
\hline \multicolumn{3}{|l|}{ History of PAT } \\
\hline Positive & 518 & $23.2 \%$ \\
\hline Negative & 1,713 & $76.8 \%$ \\
\hline \multicolumn{3}{|c|}{ History of praziquantel } \\
\hline Positive & 592 & $26.5 \%$ \\
\hline Negative & 1,639 & $73.5 \%$ \\
\hline
\end{tabular}

Note: *Age is shown by mean \pm standard deviation, followed by median and range. Abbreviation: PAT, parenteral antischistosomal therapy.

Of the 2,335 participants in the study, $315(13.5 \%)$ were HCV ribonucleic acid (RNA)-positive, and 2,020 (86.5\%) participants were $\mathrm{HCV}$ antibody-negative. The predominant genotype was genotype 4 in $98 \%$ of our studied group, while $2 \%$ were genotype $1 \mathrm{a}$. The mean age in the HCV-positive group was significantly higher ( $43.7 \pm 10.3$ years) compared to the HCV-negative group $(38.8 \pm 10.2$ years, $P<0.0001)$. The prevalence of $\mathrm{HCV}$ by age and other clinical characteristics is shown in Table 2. The overall prevalence of HCV was $13.5 \%$ (95\% CI $12.2 \%-14.9 \%)$. The prevalence of HCV in the PAT-positive population was significantly higher $(23.7 \%$, 95\% CI $20.2 \%-27.6 \%)$ compared with $11.2 \%(95 \%$ CI 9.8\%-12.8\%) in the PAT-negative population $(P<0.0001)$. Significantly higher $\mathrm{HCV}$ prevalence occurred in participants who were older than 50 years (23\%, 95\% CI 19.3\%-27.1\%) compared to age 45 to less than 50 years $(19.3 \%, 95 \% \mathrm{CI}$ $15.2 \%-23.8 \%)$, age 35 to less than 45 years $(11.1 \%, 95 \%$ CI $8.9 \%-13.7 \%)$, and age less than 35 years $(8.5 \%, 95 \% \mathrm{CI}$ $6.8 \%-10.4 \%)(P<0.0001)$. Higher prevalence occurred in the low socioeconomic group (14.2\%, 95\% CI 11.3\%-17.4\%); however, the differences between the groups did not achieve statistical significance $(P=0.614)$. There was a trend toward a higher prevalence of $\mathrm{HCV}$ in the older age groups compared to younger age $(P<0.0001)$, as presented in Table 2 .
Table 2 Prevalence of hepatitis $C$ virus by demographic and other clinical characteristics

\begin{tabular}{|c|c|c|c|}
\hline & $\mathbf{n}$ & $\begin{array}{l}\text { Percentage } \\
\text { prevalence }(95 \% \mathrm{Cl})\end{array}$ & $P$-value \\
\hline Overall & $315 / 2,335$ & $13.5(|2.2-| 4.9)$ & \\
\hline \multicolumn{4}{|l|}{ Age group } \\
\hline$<35$ years & $77 / 908$ & $8.5(6.8-10.4)$ & $<0.0001$ \\
\hline 35 to $<45$ years & $73 / 658$ & II.I (8.9-13.7) & \\
\hline 45 to $<50$ years & $62 / 322$ & $19.3(15.2-23.8)$ & \\
\hline$\geq 50$ years & $103 / 447$ & $23.0(19.3-27.1)$ & \\
\hline \multicolumn{4}{|c|}{ Residential/socioeconomic status } \\
\hline Urban & $244 / 1,834$ & $13.3(|1.8-| 4.9)$ & 0.614 \\
\hline Low & $71 / 501$ & $14.2(\mid 1.3-17.4)$ & \\
\hline \multicolumn{4}{|l|}{ History of bilharziasis } \\
\hline Positive & $134 / 605$ & $22.1(19.0-25.6)$ & $<0.0001$ \\
\hline Negative & $181 / 1,625$ & II.I (9.7-I2.7) & \\
\hline \multicolumn{4}{|l|}{ History of PAT } \\
\hline Positive & $123 / 518$ & $23.7(20.2-27.6)$ & $<0.0001$ \\
\hline Negative & $192 / 1,7 \mid 3$ & II.2(9.8-12.8) & \\
\hline \multicolumn{4}{|c|}{ History of praziquantel } \\
\hline Positive & $133 / 592$ & $22.5(19.2-26.0)$ & $<0.0001$ \\
\hline Negative & $182 / 1,639$ & II.I (9.6-12.7) & \\
\hline
\end{tabular}

Abbreviations: $\mathrm{Cl}$, confidence interval; PAT, parenteral antischistosomal therapy.

Logistic regression analysis revealed that increasing age and history of PAT, bilharziasis, and praziquantel were common risk factors and significantly associated with an increased risk for $\mathrm{HCV}$ infection. The risk of $\mathrm{HCV}$ infection was 3.2 times more likely to be higher in the age group $\geq 50$ years

Table 3 Association of various predictors with HCV: logistic regression analysis

\begin{tabular}{|c|c|c|c|c|}
\hline & $\begin{array}{l}\text { Percentage } \\
\text { of HCV }\end{array}$ & $\begin{array}{l}\text { Unadjusted } \\
\text { OR }\end{array}$ & $\begin{array}{l}95 \% \mathrm{Cl} \\
\text { for OR }\end{array}$ & $P$-value \\
\hline \multicolumn{5}{|l|}{ Age group } \\
\hline$<35$ years* & 8.5 & 1.0 & & \\
\hline 35 to $<45$ years & II.I & 1.3 & $0.97-1.89$ & 0.084 \\
\hline 45 to $<50$ years & 19.3 & 2.6 & I.79-3.70 & $<0.001$ \\
\hline$\geq 50$ years & 23.0 & 3.2 & $2.34-4.45$ & $<0.001$ \\
\hline \multicolumn{5}{|c|}{ Residential/socioeconomic status } \\
\hline Urban* & 5.6 & 1.0 & & 0.614 \\
\hline Low & 12.4 & 1.1 & $0.8 \mathrm{I}-1.43$ & \\
\hline \multicolumn{5}{|l|}{ History of bilharziasis } \\
\hline Negative* & II.I & 1.0 & & \\
\hline Positive & 22.1 & 2.3 & $1.77-2.90$ & $<0.001$ \\
\hline \multicolumn{5}{|l|}{ History of PAT } \\
\hline Negative* & 11.2 & 1.0 & & \\
\hline Positive & 23.7 & 2.5 & $1.92-3.17$ & $<0.001$ \\
\hline \multicolumn{5}{|c|}{ History of praziquantel } \\
\hline Negative* & II.I & 1.0 & & \\
\hline Positive & 22.5 & 2.3 & $\mathrm{I} .8 \mathrm{I}-2.97$ & $<0.001$ \\
\hline
\end{tabular}

Note: *Subjects in this category served as the reference group.

Abbreviations: $\mathrm{HCV}$, hepatitis $\mathrm{C}$ virus; $\mathrm{OR}$, odds ratio; $\mathrm{Cl}$, confidence interval; PAT, parenteral antischistosomal therapy. 
(OR 3.2, 95\% CI 2.34 4.45; $P<0.001$ ) compared to $<35$ years. Participants who were positive for HCV infection were nearly 2.5 times as likely to be positive for PAT (OR 2.5, 95\% CI 1.92-3.17; $P<0.001), 2.3$ times as likely to be positive for bilharziasis (OR 2.3, 95\% CI 1.77-2.90; $P<0.001$ ), and 2.3 times as likely to be positive for praziquantel (OR 2.3, 95\% CI 1.81-2.97; $P<0.001)$ compared to those who were negative for $\mathrm{HCV}$ infection (Table 3 and Figure 1). Using multivariable logistic regression analysis controlling for all other potential covariates and predictors, such as age, history of PAT, bilharziasis, praziquantel, and residential area, we found that the factors with the strongest and significant association with HCV infection were among persons 35 to more than 50 years old and history of praziquantel. No significant interactions were found between age, history of PAT, bilharziasis, and praziquantel, and including an interaction term in the model had no effect on the adjusted OR, as shown in Table 4.

\section{Discussion}

The persistently high prevalence of HCV among Egyptians is still an unexplained mystery. Although the introduction of oral praziquantel for the treatment of schistosomiasis in 1982 halted the iatrogenic mode of transmission, and the current extremely low prevalence of Schistosoma mansoni infection (2.4\%), ${ }^{12}$ the incidence of HCV in Egypt seems to be continuing at a rate of $\sim 6.9 / 1,000$ persons per year, indicating a possibly ongoing hyperepidemic transmission. ${ }^{3}$

Increasing HCV prevalence has consistently been found to be associated with age in all reports. The decreased prevalence among the population born after $1986^{3}$ coincided with the discontinuation of the PAT. As low as $0.5 \%$ prevalence was also reported in those below 30 years, increasing to a peak of $4.2 \%$ between 40 and 53 years of age. ${ }^{10}$ On the contrary, our report showed high prevalence $(8.5 \%)$ among patients aged $<35$ years, increasing with age, which is in accordance

Table 4 Association of various predictors with $\mathrm{HCV}$ : multivariate logistic regression analysis

\begin{tabular}{|c|c|c|c|c|}
\hline & $\begin{array}{l}\text { Percentage } \\
\text { of } \mathrm{HCV}\end{array}$ & $\begin{array}{l}\text { Adjusted } \\
\text { OR }\end{array}$ & $\begin{array}{l}95 \% \mathrm{Cl} \\
\text { for OR }\end{array}$ & $P$-value \\
\hline \multicolumn{5}{|l|}{ Age group } \\
\hline$<35$ years $*$ & 8.5 & 1.0 & & \\
\hline 35 to $<45$ years & 11.1 & 1.2 & $0.87-1.73$ & 0.235 \\
\hline 45 to $<50$ years & 19.3 & 2.2 & $\mid .5 \mathrm{I}-3.2 \mathrm{I}$ & $<0.001$ \\
\hline$\geq 50$ years & 23.0 & 2.7 & $1.88-3.75$ & $<0.001$ \\
\hline \multicolumn{5}{|c|}{ History of praziquantel } \\
\hline Negative* & 11.1 & 1.0 & & \\
\hline Positive & 22.5 & 1.7 & $1.29-2.21$ & $<0.001$ \\
\hline
\end{tabular}

Note: *Subjects in this category served as the reference group.

Abbreviations: $\mathrm{HCV}$, hepatitis $\mathrm{C}$ virus; $\mathrm{OR}$, odds ratio; $\mathrm{Cl}$, confidence interval. with previous reports that confirmed a very high $\mathrm{HCV}$-antibody prevalence in Egypt. ${ }^{13,14}$ In our opinion, the relatively high prevalence we report below the age of 35 that increases with age is most likely attributed to the sample group, as most of them were farmers from rural areas with low education, where high prevalence was reported to be as high as $27.4 \% .{ }^{15}$ Also, living in rural areas and in Lower and Upper Egypt was reported to be an independent risk factor for high prevalence, being related to many factors, such as parent-to-child undetected mode of transmission, ${ }^{16}$ vertical transmission, iatrogenic factors, perinatal infection, intrafamilial and interspousal transmission, nonsterile medical and dental activities, IDU, poor education, circumcision by an informal health care provider, ${ }^{17}$ and shaving by community barbers. ${ }^{18}$ Nevertheless, none of these factors is enough to explain the intense ingoing infection in Egyptians aged $<35$ years.

Vertical transmission has been suggested as responsible for an overall adjusted rate as low as $1.7 \% .{ }^{19}$ El-Kamary et al and Shebl et al reported that early and late clearance of infection through specific cell-mediated immunity occurs frequently, but only $2.4 \%$ of Egyptian infants born of $\mathrm{HCV}$ RNA-positive mothers had detectable HCV RNA at 2-3 years of age. ${ }^{20,21}$ Furthermore, the incidence of HCV infection was not significantly associated with the child's sex, mode or place of delivery, or type of delivery attendants present at the birth. ${ }^{7}$ Also, previous delivery of an infected child was not found to increase the risk of transmission in subsequent pregnancies. ${ }^{16}$ It was therefore concluded that the frequency of vertical transmission of HCV in Egypt does not seem to play a role in the high prevalence of HCV in Egypt. ${ }^{22}$

Perinatal infection occurs in up to $5 \%$ of $\mathrm{HCV}$-infected mothers, and the presence of HCV RNA in breast milk has been reported. Nevertheless, recent reports showed that breast milk possesses an antiviral effect linked to endogenous lipase-dependent generation of free fatty acids that destroy the viral lipid envelope, and is thus unlikely to play a major role in vertical transmission. ${ }^{23}$

Reports regarding interspousal transmission are contradictory. While Magder et al estimated through mathematical modeling that $6 \%$ of infected individuals in rural areas in Egypt acquired infection from their spouses, ${ }^{24}$ cohort studies from Italy and Turkey reported very low rates over several years of follow-up per couple. ${ }^{25,26}$ The risk of sexual transmission of $\mathrm{HCV}$ within heterosexual monogamous couples is also extremely low or even nil. ${ }^{27}$ Consequently, $\mathrm{HCV}$ is classically considered as poorly contagious within families or between spouses, and this mode of transmission remains an issue of debate. ${ }^{26}$ 


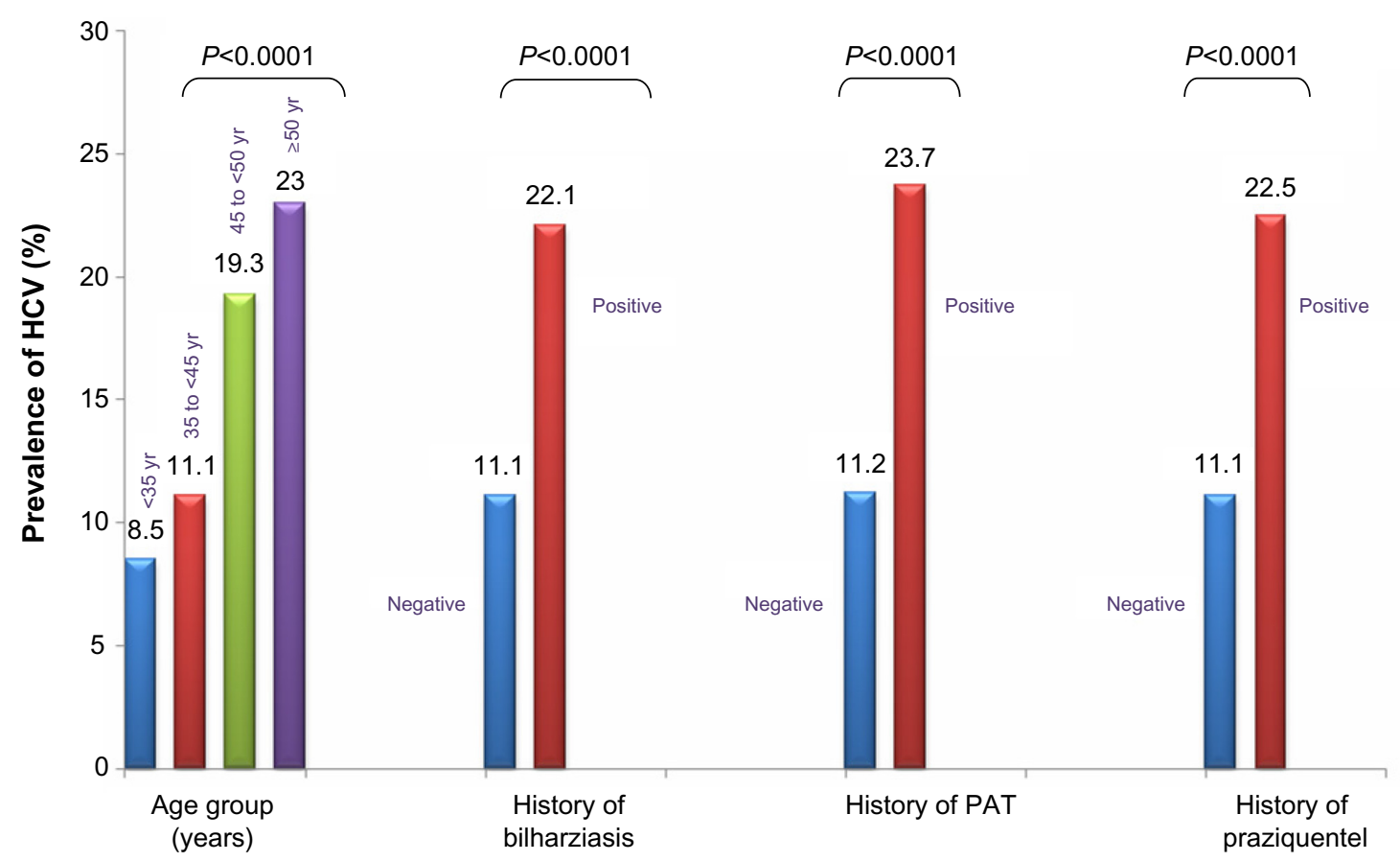

Figure I Prevalence of HCV by age and other clinical characteristics.

Abbreviations: HCV, hepatitis C virus; PAT, parenteral antischistosomal therapy; yr, years.

Dental care, another risk factor, was unlikely the cause in our study. In spite of the insignificant difference in dental care sessions among HCV-positive and -negative cases in our studied group of patients, which was in accordance with Egyptian and Iranian reports, ${ }^{6,28-30}$ they were all followed in the same health centers, suggesting that factors other than malpractice and iatrogenic role were involved. Nonsterile medical and dental activities have been convincingly shown as important in this regard, ${ }^{26,28}$ but little or no evidence has been provided that these practices are more prevalent in Egypt than other middle-income countries with low HCV prevalence. Different dental procedures were evaluated, and interestingly, despite initial results in some studies showing an association between $\mathrm{HCV}$ and dental treatment, when further analysis was applied, Habib et al found no difference in receiving dental treatment between infected and noninfected studied groups after adjusting for the age of the participants. ${ }^{31}$

The prevalence of HCV antibodies among Egyptianborn persons living in New York City was $15.6 \%$, in spite of an absence of iatrogenic exposures. ${ }^{32,33}$ In our study and another, ${ }^{31}$ the tested subjects came from similar villages, each served by one health center and dental care unit with similar standards of practice, and most health centers utilize infection-precautionary methods, which raises the question about why only $8 \%$ are exposed to infection. Though an important risk, iatrogenic factors cannot explain the high intense ongoing infection compared to other countries.
Circumcision, a practice followed at birth by all Muslim males in Egypt, is another potential risk, but positive cases are only $8 \%$, and even non-Muslims who do not follow this practice also tested positive for $\mathrm{HCV}$. It was therefore concluded that circumcision has a low risk for $\mathrm{HCV}$ transmission, ${ }^{32}$ because almost everyone in a village had been exposed, but a limited number got infected.

Poor education in rural areas and unawareness of modes of HCV transmission other than contact with blood among Egyptians have been suggested as causes of the persistence of infection, but Chemaitelly et al did not demonstrate any association between HCV knowledge and HCV infection among the adult population of Egypt. ${ }^{34,35}$ They also concluded that the effect of awareness on reducing the risk of $\mathrm{HCV}$ infection may not provide sufficient empowerment for individuals to avoid $\mathrm{HCV}$ infection and should be complemented with prevention programs. The relative contribution of IDU to HCV incidence and prevalence in Egypt is much smaller than that in other countries, ${ }^{36}$ and none of our seropositive cases had experienced IDU.

The relation between the prevalence of $\mathrm{HCV}$, schistosomal infestation, and PAT is also controversial. Numerous contemporary studies and the current one have found that less than 20\% of those testing HCV-seropositive in Egypt have a history of exposure to PAT. ${ }^{35}$ Furthermore, numerous other countries have experienced similarly intense mass intravenous injection campaigns with inadequate 
attention to injection sterility, but without dramatic $\mathrm{HCV}$ epidemics. ${ }^{36,37}$ Sudan, a country geographically close to Egypt with similar schistosomiasis endemicity and a medical service with almost the same level of malpractice, in addition to predominance of HCV genotype 4, surprisingly has a low seroprevalence $(2.3 \%)$ of $\mathrm{HCV}$ among patients with bilharzial hepatosplenomegaly who received parenteral therapy. ${ }^{38,39}$

Even with the termination of PAT campaigns and the implementation of more stringent infection-control measures, we report considerable prevalence levels among our subjects below the age of 35 years. Having all been exposed to the same risk factors, only $8.5 \%$ got infected, $11 \%$ of negative subjects had received PAT, only $24 \%$ of PAT-positive tested $\mathrm{HCV}$-positive, and only some offspring members of the same families were infected. Not only that, but as opposed to other countries where HCV dynamics are focused in specific highrisk groups, such as IDU and hemodialysis, HCV transmission in Egypt has reached diverse population groups, including those not conventionally identified to be at risk of infection. ${ }^{13}$ Moreover, some patients remained unaffected despite repeated exposure to risk factors. The question remains: why are some members of the Egyptian population more susceptible to infection while others are resistant? And why are Egyptians at high risk while the risk factors are comparable to other countries?

Recently, the involvement of host genetic factors in susceptibility/resistance to $\mathrm{HCV}$ infection in endemic countries has been suggested, and a dominant major gene conferring predisposition to $\mathrm{HCV}$ infection has been postulated. ${ }^{40}$ The association of the human leukocyte antigen (HLA) system with HCV infection in Egyptian populations has been addressed in two studies, where HLA-A29 was found to be associated with HCV infection, ${ }^{41}$ and HLAA9 was associated with low $\mathrm{HCV}$ viral load. ${ }^{42}$ In addition, a negative association between HLA allelic DRB1-11 and susceptibility to HCV was reported. ${ }^{43}$ Genetic predisposition to infection was also proposed in intrafamilial transmission. ${ }^{42}$ Lymphotoxin- $\alpha$ may also have a role in susceptibility to HCV infection in Egypt. ${ }^{44}{ }^{46}$ Genetic variants in estrogen receptor- $\alpha$ were found to be associated with HCV infection that may play an important role in determining the susceptibility to HCV susceptibility and viral clearance in a high-risk Chinese population. ${ }^{47}$ In Japanese, common amino acid substitution in HLA-DQB1 was implicated in susceptibility to chronic infection. ${ }^{48}$

Because of limitations in the sex of the sample, all being males, which may have affected the results, reflecting the higher rate of exposure of Egyptian males to both schistosomiasis and/or HCV and immigration for work outside Egypt, we recommend further studies including females to validate our results.

\section{Conclusion}

We conclude that the high prevalence below the age of 35 years in the absence of iatrogenic factors suggests a change in the pattern of HCV spread. We still need to understand the exact causes behind susceptibility to improve preventive measures. Host genetic predisposition seems to be a plausible underlying factor. Whether these alleged host genetic factors will affect the response and/or mutation to the new direct-acting antiviral drugs is an important yet unanswered question.

\section{Disclosure}

The authors report no conflicts of interest in this work.

\section{References}

1. Williams R. Global challenges in liver disease. Hepatology. 2006;44(3):521-526.

2. Mohd Hanafiah K, Groeger J, Flaxman AD, Wiersma ST. Global epidemiology of hepatitis $C$ virus infection: new estimates of age-specific antibody to HCV seroprevalence. Hepatology. 2013;57(4):1333-1342.

3. Miller FD, Abu-Raddad LJ. Evidence of intense ongoing endemic transmission of hepatitis C virus in Egypt. Proc Natl Acad Sci U S A. 2010;107(33):14757-14762.

4. Frank C, Mohamed MK, Strickland GT, et al. The role of parenteral antischistosomal therapy in the spread of hepatitis C virus in Egypt. Lancet. 2000;355(9207):887-891.

5. Arafa N, El Hoseiny M, Rekacewicz C, et al. Changing patterns of hepatitis $\mathrm{C}$ virus spread in rural areas of Egypt. $J$ Hepatol. 2005;43(3):418-424.

6. Mostafa A, Taylor SM, el-Daly M, et al. Is the hepatitis C virus epidemic over in Egypt? Incidence and risk factors of new hepatitis $\mathrm{C}$ virus infections. Liver Int. 2010;30(4):560-566.

7. Saleh DA, Shebl F, Abdel-Hamid M, et al. Incidence and risk factors for hepatitis $\mathrm{C}$ infection in a cohort of women in rural Egypt. Trans R Soc Trop Med Hyg. 2008;102(9):921-928.

8. Shebl FM, El-Kamary SS, Saleh DA, et al. Prospective cohort study of mother-to-infant infection and clearance of hepatitis $\mathrm{C}$ in rural Egyptian villages. J Med Virol. 2009;81(6):1024-1031.

9. Plancoulaine S, Mohamed MK, Arafa N, et al. Familial correlations in hepatitis $\mathrm{C}$ virus (HCV) seroprevalence suggests intrafamilial viral transmission and genetic predisposition to infection. Gut. 2008;57(9):1268-1274.

10. Hussein E, Teruya J. Evaluation of blood supply operation and infectious disease markers in blood donors during the Egyptian revolution. Transfusion. 2012;52(11):2321-2328.

11. Bakr I, Rekacewicz C, El Hosseiny M, et al. Higher clearance of hepatitis $\mathrm{C}$ virus infection in females compared with males. Gut. 2006;55(8):1183-1187.

12. Daniel HD, Abraham P, Raghuraman S, Vivekanandan P, Subramaniam T, Sridharan G. Evaluation of a rapid assay as an alternative to conventional enzyme immunoassays for detection of hepatitis $\mathrm{C}$ virus-specific antibodies. J Clin Microbiol. 2005;43(4):1977-1978.

13. Guerra J, Garenne M, Mohamed MK, Fontanet A. HCV burden of infection in Egypt: results from a nationwide survey. $J$ Viral Hepat. 2012;19(8):560-567. 
14. Mohamoud YA, Mumtaz GR, Riome S, Miller D, Abu-Raddad LJ. The epidemiology of hepatitis $C$ virus in Egypt: a systematic review and data synthesis. BMC Infect Dis. 2013;13:288.

15. El-Sadawy M, Ragab H, el-Toukhy H, et al. Hepatitis C virus infection at Sharkia Governorate, Egypt: seroprevalence and associated risk factors. J Egypt Soc Parasitol. 2004;34(Suppl 1):367-384.

16. Indolfi G, Azzari C, Resti M. Perinatal transmission of hepatitis C virus. $J$ Pediatr. 2013;163(6):1549-1552. e1.

17. Medhat A, Shehata M, Magder LS, et al. Hepatitis C in a community in Upper Egypt: risk factors for infection. Am J Trop Med Hyg 2002;66(5):633-638.

18. Al-Rabeei NA, Al-Thaifani AA, Dallak AM. Knowledge, attitudes and practices of barbers regarding hepatitis $\mathrm{B}$ and $\mathrm{C}$ viral infection in Sana'a city, Yemen. J Community Health. 2012;37(5):935-939.

19. Goldberg E, Shopra S, O’Donovan D. Vertical transmission of hepatitis C virus. 2014. Available from: http://www.uptodate.com/contents/ vertical-transmission-of-hepatitis-c-virus. Accessed August 18, 2014.

20. Shebl FM, El-Kamary SS, Saleh DA, et al. Prospective cohort study of mother-to-infant infection and clearance of hepatitis $\mathrm{C}$ in rural Egyptian villages. J Med Virol. 2009;81(6):1024-1031.

21. El-Kamary SS, Hashem M, Saleh DA, et al. Hepatitis C virus-specific cell-mediated immune responses in children born to mothers infected with hepatitis C virus. J Pediatr. 2013;162(1):148-154.

22. AbdulQawi K, Youssef A, Metwally MA, Ragih I, AbdulHamid M, Shaheen A. Prospective study of prevalence and risk factors for hepatitis $\mathrm{C}$ in pregnant Egyptian women and its transmission to their infants. Croat Med J. 2010;51(3):219-228.

23. Pfaender S, Heyden J, Friesland M, et al. Inactivation of hepatitis $\mathrm{C}$ virus infectivity by human breast milk. J Infect Dis. 2013;208(12):1943-1952.

24. Magder LS, Fix AD, Mikhail NN, et al. Estimation of the risk of transmission of hepatitis $\mathrm{C}$ between spouses in Egypt based on seroprevalence data. Int J Epidemiol. 2005;34(1):160-165.

25. Vandelli C, Renzo F, Romanò L, et al. Lack of evidence of sexual transmission of hepatitis $\mathrm{C}$ among monogamous couples: results of a 10-year prospective follow-up study. Am J Gastroenterol. 2004;99(5):855-859.

26. Tahan V, Karaca C, Yildirim B, et al. Sexual transmission of HCV between spouses. Am J Gastroenterol. 2005;100(4):821-824.

27. Terrault NA, Dodge JL, Murphy EL, et al. Sexual transmission of hepatitis $\mathrm{C}$ virus among monogamous heterosexual couples: the $\mathrm{HCV}$ partners study. Hepatology. 2013;57(3):881-889.

28. Paez Jimenez A, Sharaf Eldin N, Rimlinger F, et al. HCV iatrogenic and intrafamilial transmission in Greater Cairo, Egypt. Gut. 2010;59(11):1554-1560.

29. Stoszek SK, Abdel-Hamid M, Narooz S, et al. Prevalence of and risk factors for hepatitis $\mathrm{C}$ in rural pregnant Egyptian women. Trans $R$ Soc Trop Med Hyg. 2006;100(2):102-107.

30. Hajiani E, Masjedizadeh R, Hashemi J, Azmi M, Rajabi T. Hepatitis $\mathrm{C}$ virus transmission and its risk factors within families of patients infected with hepatitis $\mathrm{C}$ virus in southern Iran: Khuzestan. World J Gastroenterol. 2006;12(43):7025-7028.

31. Habib M, Mohamed MK, Abdel-Aziz F, et al. Hepatitis C virus infection in a community in the Nile Delta: risk factors for seropositivity. Hepatology. 2001;33(1):248-253.

32. Awadalla HI, Ragab MH, Nassar NA, Osman MA. Risk factors of hepatitis $\mathrm{C}$ infection among Egyptian blood donors. Cent Eur J Public Health. 2011;19(4):217-221.

Clinical and Experimental Gastroenterology

\section{Publish your work in this journal}

Clinical and Experimental Gastroenterology is an international, peerreviewed, open access journal, publishing all aspects of gastroenterology in the clinic and laboratory, including: Pathology, pathophysiology of gastrointestinal disease; Investigation and treatment of gastointestinal disease; Pharmacology of drugs used in the alimentary tract;
33. Perumalswami PV, Miller FD, Orabee H, et al. Hepatitis C screening beyond CDC guidelines in an Egyptian immigrant community. Liver Int. 2014;34(2):253-258.

34. Murad EA, Babiker SM, Gasim GI, Rayis DA, Adam I. Epidemiology of hepatitis $\mathrm{B}$ and hepatitis $\mathrm{C}$ virus infections in pregnant women in Sana'a, Yemen. BMC Pregnancy Childbirth. 2013;13:127.

35. Chemaitelly H, Abu-Raddad LJ, Miller FD. An apparent lack of epidemiologic association between hepatitis $\mathrm{C}$ virus knowledge and the prevalence of hepatitis $\mathrm{C}$ infection in a national survey in Egypt. PLoS One. 2013;8(7):e69803.

36. Paez Jimenez A, Mohamed MK, Eldin NS, et al. Injection drug use is a risk factor for $\mathrm{HCV}$ infection in urban Egypt. PLoS One. 2009;4(9):e7193.

37. Guerra J, Garenne M, Mohamed MK, Fontanet A. HCV burden of infection in Egypt: results from a nationwide survey. J Viral Hepat. 2012;19(8):560-567.

38. Pépin J, Lavoie M, Pybus OG, et al. Risk factors for hepatitis C virus transmission in colonial Cameroon. Clin Infect Dis. 2010;51(7): 768-776.

39. Mullis CE, Laeyendecker O, Reynolds SJ, et al. High frequency of false-positive hepatitis $\mathrm{C}$ virus enzyme-linked immunosorbent assay in Rakai, Uganda. Clin Infect Dis. 2013;57(12):1747-1750.

40. Mudawi HM, Smith HM, Fletcher IA, Fedail SS. Prevalence and common genotypes of HCV infection in Sudanese patients with hepatosplenic schistosomiasis. J Med Virol. 2007;79(9): $1322-1324$.

41. Gasim GI, Hamdan HZ, Hamdan SZ, Adam I. Epidemiology of hepatitis $\mathrm{B}$ and hepatitis $\mathrm{C}$ virus infections among hemodialysis patients in Khartoum, Sudan. J Med Virol. 2012;84(1):52-55.

42. Laouénan C, Plancoulaine S, Mohamed MK, et al. Evidence for a dominant major gene conferring predisposition to hepatitis $\mathrm{C}$ virus infection in endemic conditions. Hum Genet. 2009;126(5): 697-705.

43. Zekri AR, El-Mahallawy HA, Hassan A, El-Din NH, Kamel AM. HLA alleles in Egyptian HCV genotype-4 carriers. Egypt J Immunol. 2005;12(1):77-86.

44. Mosaad YM, Farag RE, Arafa MM, et al. Association of human leucocyte antigen class I (HLA-A and HLA-B) with chronic hepatitis $\mathrm{C}$ virus infection in Egyptian patients. Scand J Immunol. 2010;72(6):548-553.

45. Grimaldi V, Sommese L, Picascia A, et al. Association between human leukocyte antigen class I and II alleles and hepatitis $\mathrm{C}$ virus infection in high-risk hemodialysis patients awaiting kidney transplantation. Hum Immunol. 2013;74(12):1629-1632.

46. Elsammak MY, Al-Sharkaweey RM, Ragab MS, Amin GM, Kandil MH. In Egyptians, a mutation in the lymphotoxin-alpha gene may increase susceptibility to hepatitis $\mathrm{C}$ virus but not that to schistosomal infection. Ann Trop Med Parasitol. 2008;102(8): 709-716.

47. Tang S, Yue M, Wang J, Su J, et al. Association of genetic variants in estrogen receptor $\alpha$ with $\mathrm{HCV}$ infection susceptibility and viral clearance in a high-risk Chinese population. Eur J Clin Microbiol Infect Dis. 2014;33(6):999-1010.

48. Miki D, Ochi H, Takahashi A, et al. HLA-DQB1*03 confers susceptibility to chronic hepatitis $\mathrm{C}$ in Japanese: A genome-wide association study. PLoS One. 2013;8(12):e84226. 